\title{
A Bibliographical Survey on Integration of Hybrid Renewable Energy Sources with Diesel Generator and Storage System
}

\author{
Ravi Dharavath*, I. Jacob Raglend, S. Prabhakar Karthikeyan and J. Belwin Edward
}

School of Electrical Engineering, VIT University, Vellore, India

Received 22 January 2018; Accepted 5 November 2018

\begin{abstract}
The power consumption has increased enormously due to the intervention of high end technology and it is necessary to meet this power demand. The power pushed into any electrical system should be highly reliable, secured with sufficient quantity and quality. One such solution is to bring reliable and flexible power by introducing Hybrid energy systems into the network. The main motivation of hybrid energy systems is to improve the delivery of power at the utilities and customer end. In this paper, a complete literature review is made on the integration of solar photovoltaic, wind and diesel generator with energy storage systems like hydrogen based fuel cells and batteries. This hybrid system reduces the operating time of diesel generator, save the fuel consumption and hence accomplishes the peak demand with diesel generator.
\end{abstract}

Keywords: Solar PV, Wind, Diesel, Battery, Fuel cell.

\section{Introduction}

One of the major sources for a country to develop economically is energy. In any country, utilization of electrical energy increases due to technology, population growth and economic development. The increasing demand of energy consumption is becoming prominent in the agricultural, industrial and domestic sector [1] and the author has reviewed on planning and control strategies with respect to renewable and sustainable energy. The installed capacity of the electrical utility sector in India was $307.28 \mathrm{GW}$ as on $31^{\text {st }}$ October 2016 and renewable power plant capacity was $28.9 \%$ of the total installed capacity [2]. The shortage of power during peak demand in India with a capacity of 2,329MW as of Jul 2017, [3] was reported by the Ministry of Power, Government of India. The shortage of power and energy demand was reduced gradually every year. The shortages of power and energy details of last three years are mentioned in Tab.1.

Table 1. The summary of shortage of power and energy demand for last three years in India [3]

\begin{tabular}{c|c|c|c}
\hline SI.No. & $\begin{array}{c}\text { Month } \\
\text { and Year }\end{array}$ & $\begin{array}{c}\text { Power } \\
\text { demand of } \\
\text { shortage } \\
\text { (MW) }\end{array}$ & $\begin{array}{c}\text { Energy demand } \\
\text { shortage (MU) }\end{array}$ \\
\hline 1 & Jul 2017 & 2,329 & 12 \\
2 & Jul 2016 & 2,549 & 14 \\
3 & Jul 2015 & 3,486 & 61 \\
\hline
\end{tabular}

The authors have found that the demand for electricity can be raised around 2280BKwh by 2021-22[4] and the usage of energy from the world context could rise to $53 \%$ by

*E-mail address: rv.dharavath@gmail.com

ISSN: 1791-2377 @ 2018 Eastern Macedonia and Thrace Institute of Technology. All rights reserved. doi:10.25103/jestr.115.08
2035 [5]. Non-renewable and renewable energy sources [6] play a vital role in the energy consumption and both the energy sources are creating high impact with economic growth and emission of carbon relationship. But the coal based plant causes environmental pollution, such as Acid rains, global warming [7] [8] and the emission of greenhouse gasses which leads to changes in the climate.

In order to avoid environmental pollution, the electric capacity can be increased with the help of renewable sources like hydro, wind, solar etc. Renewable energy sources are the back bone of current green economy effort and can affect the biodiversity and ecosystems [9]. Nowadays the most prominent renewable sources are solar, wind sources and these sources are more economical in the generation of electricity. The single photovoltaic system cannot meet the peak load continuously due to the dynamic variation in climate. Energy backup is needed to meet peak power demand and provide continues supply, and this energy backup system is called storage system.

In solar PV system, the battery is used to improve its performance but it cannot support for a long time. The integration of the Photovoltaic system with diesel and battery hybrid standalone system is reliable compared to Photovoltaic-battery integrated system. This integration of photovoltaic systems increases the efficiency and saves the fuel consumption of diesel generator. It also improves the stability of the solar PV system and load can be met satisfactorily. The output from solar-diesel-battery is optimized with different solar irradiance varying from 0$100 \%$ and the parameter variation such as radiance, cost of the diesel, load consumption are analysed to save the intake fuel and energy cost [10].

The peak demand may not be sufficient to meet with the integration of single Diesel generator and battery simultaneously. An alternative solution is by integrating 
wind energy with photovoltaic systems which is also favourable to the environment. As the nature of solar, wind and other renewable energy sources are intermittent, the individual sources are unable to meet the peak load and to supply continuous power.

To have flexibility, the generation of electricity is enhanced with the hybrid renewable energy sources and it reduces the effect of greenhouse gasses [11]. The authors in [12] have realized the hybrid system through an experimental set up from which size optimisation and real time performance are studied. The efficiency of solar PV and the wind energy is enhanced with novelty in the integration of doubly fed induction generator based wind turbine with both rotor and grid side converter control. This system is used for injecting large power into the grid [13].

In this paper, the following section deals with brief description on solar PV system, wind energy system, Diesel generation, storage system and Fuel cell. A complete literature review is made on the integration of all sources mentioned above.

\section{Photovoltaic (PV) System}

Solar energy is produced from solar radiation due to which heat energy is exploited. Solar PV system [14] converts incident sunlight into electricity by the principle of photoelectric effect. This solar storage technology is developed with reduced energy payback time and the device by using conventional silicon and carbon based scalable material is achieved [15]. The Solar PV cell is a basic nonlinear device of PV system and it is shown in Fig.1. [16]. These PV cells are arranged in a series-parallel configuration such that an array is formed.

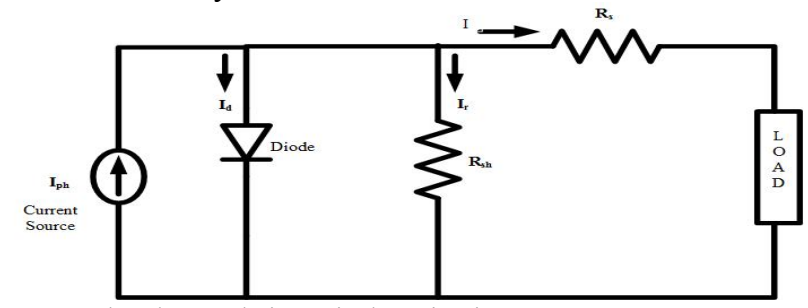

Fig. 1. Solar photo voltaic equivalent circuit [16]

The voltage-current relation of the PV array model is obtained from Eq.1 and Eq.2.

$$
\begin{aligned}
& V_{P V}=\frac{n K T}{q} \ln \left(\frac{I_{s c}}{I_{p v}}+1\right) \\
& I_{p v}=I_{s c}-I_{p v o}\left[\exp \left(\frac{q\left(V_{p v}+I_{p v} R_{s}\right)}{N_{s} K T n}\right)-1\right]-\frac{V_{p v}+R_{s} I_{s c}}{R_{s h}}
\end{aligned}
$$

The various sustainable technologies were developed with the solar building system [17] and the status of utilization of solar energy in India along with its applications, battery integration with the solar photovoltaic system [18] is presented. The various photovoltaic monitoring techniques, measuring instruments and the offgrid/ on-grid PV systems is proposed to improve the performance of solar energy systems[19].The author has emphasized the significance and benefits of solar PV panels by illustrating the growth in solar PV technology since 2010 to 2014 for off-grid and on-grid system [20].

The author has reviewed 31 maximum power point trackingmethodswith13 parameters altogether and has explored a methodology to maximize the power in solar technology [21]. In [22], the author has discussed different maximum power tracking methods such as perturbation and observation, incremental conductance with intelligent techniques and a comparison is made based on the hardware design and observation of the results. A novel high performance with high gain and efficiency of stand-alone solar PV system is investigated along with an energy storage system [23] and required power tracking method is employed for DC-DC converter to achieve high efficiency.

In grid connected mode, the active power is injected into the grid without Phase locked Loop (PLL) synchronizing unit by maintaining the appropriate reactive power to the load [24].Integration of the disposable photovoltaic system [25] is explored for smart grid application with electrical power network to provide a balanced power supply, avoid voltage fluctuation and reversal power flow from the grid. Solar thermal energy is used for heap bioleaching process [26] to increase the heap temperature. Solar power is utilized for different applications such as light, heating, thermal loading etc.

\section{Wind Energy System}

Electrical energy is developed from the wind energy system in two steps. Firstly, the wind energy is converted into mechanical energy with the help of wind turbines and then in the second stage, the mechanical energy is converted to electrical energy with the help of a generator. The mechanical power [27] from the wind turbine is expressed as shown in Eq.3.

$$
P_{m}=0.5 \rho A C_{p} \vartheta^{3}
$$

Tip speed ratio is given by the Eq.4.

$$
T S R=\gamma=\frac{\omega R}{\vartheta}
$$

Wind turbine generator starts rotating if the speed exceeds the cut-in speed and it will generate the electricity constantly if the speed reaches its rated value. The wind generator is protected if the speed of the wind exceeds its cut-out value. Power developed from individual generators at time ' $t$ ' can be obtained by the following Eq.5 [28].

$$
P_{W G}(t)=\left\{\begin{array}{l}
P_{r-W G} \frac{\vartheta(t)-\vartheta_{c u t-i n}}{\vartheta_{r}(t)-\vartheta_{c u t-i n}} \rightarrow \vartheta<\vartheta(t)<\vartheta_{r} \\
P_{r-W G} \rightarrow \vartheta_{r}<\vartheta(t)<\vartheta_{c u t-o u t} \\
0 \rightarrow \vartheta(t) \leq \vartheta_{\text {cut-in }} \text { or } \vartheta(t) \geq \vartheta_{\text {cut-out }}
\end{array}\right.
$$
Eq.6.

The overall developed power can be estimated using

$$
P_{W G}(T)=N_{\text {wind }} \times P_{W G}(t)
$$


Number of wind turbines estimated according to load requirement as shown in Eq.7.

$$
N_{\text {turbine }}=\frac{P_{L} \times S F}{P_{W G}}
$$

Advance design and control mechanism in wind generation with variable speed leads to tap the energy with high efficiency [29]. A reliability study on peak demand power in the existing fuel based generation integrated with wind using stochastic optimization technique is carried out by the authors [30]. The author in [31] inferred that wind generation with various maximum power tracking techniques perform well for desired responses and the methods are compared

\section{Diesel Generation System}

The diesel generator plays a major role during peak load and other abnormal conditions. It can be used in two ways; one as energy backup and another by connecting the load directly. In [32], ON/OFF control strategy is implemented for a diesel generator to minimize the operating cost of the hybrid energy system and for optimizing the power flowing to the on-linear load. Power pinch analysis for the hybrid configuration is suggested in [33] to minimize the consumption of fuel in diesel generator by sharing the load with renewable energy sources. Back propagation feed forward algorithm and incremental conductance based winddiesel micro grid is presented in [34] and is discussed for regulating the voltage and frequency when DG is fed to three phase load. The Diesel engine generation system mainly consists of three parts, such as Diesel Engine, Synchronous Generator and the excitation system, and the block diagram is shown in Fig.2.Excitation system provides variable DC current to maintain the desired terminal voltage.

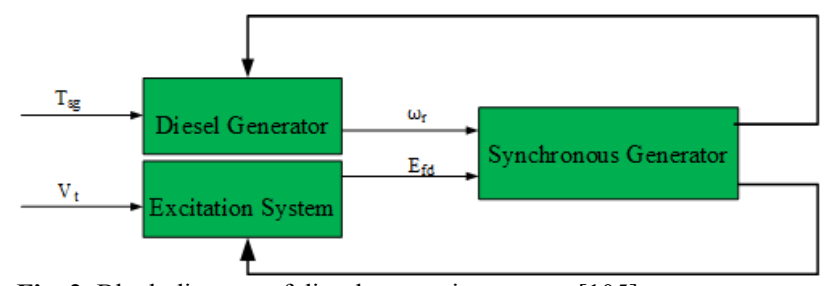

Fig. 2. Block diagram of diesel generation system [105]

Diesel engine converts the fuel flow into mechanical torque. Internal combustion engine speed is varied by regulating the fuel flow with the help of actuator and electromechanical devices. Speed controller is used to maintain the constant speed. Dynamic effect of engine inertia is estimated by relating the intake fuel and flywheel speed.

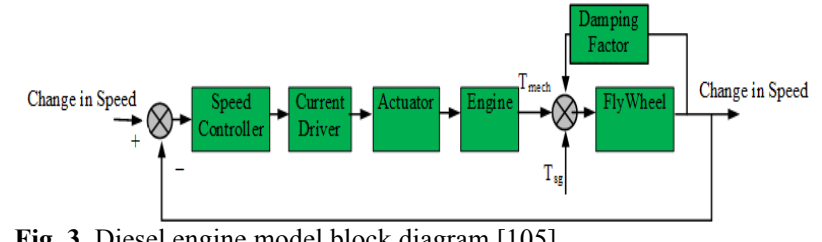

Fig. 3. Diesel engine model block diagram [105]

The transfer model of the diesel engine diagram is shown in Fig.3, and the engine mechanical motion can be represented as shown in Eq.8.

$$
T_{m e c h}(s)=k_{1} \phi(s) e^{-t_{1} s}
$$

Two axis dq-model of synchronous generator are obtained using park equation and electromagnetic torque is shown in Eq.9.

$T_{s g}=E_{d}^{\prime \prime} I_{d}+E_{q}^{\prime \prime} I_{q}-\left(X_{d}^{\prime}-X_{q}^{\prime \prime}\right) I_{d} I_{q}$

Where $I_{d}$ and $I_{q}$ are stator and rotor current flowing through the respective winding and dynamic equations of rotor are shown in Eq.10, Eq.11 and Eq.12,

$$
E_{d}^{\prime \prime}=\frac{X_{d}-X_{q}^{\prime}}{1+\tau_{q o}^{\prime} s} I_{q}
$$

$E_{q}^{\prime \prime}=\frac{1}{1+\tau_{d o}^{\prime} s} E_{q}^{\prime}-\left(\frac{X_{d}^{\prime}-X_{d}^{\prime \prime}}{1+\tau_{d o}^{\prime} s}\right) I_{d}$

$$
E_{q}^{\prime}=\frac{1}{\frac{X_{d}-X_{d}^{\prime \prime}}{X_{d}^{\prime}-X_{d}^{\prime \prime}}+\tau_{d o}^{\prime} S} E_{f d}+\left(\frac{\frac{X_{d}-X_{d}^{\prime \prime}}{X_{d}^{\prime}-X_{d}^{\prime \prime}}}{\frac{X_{d}-X_{d}^{\prime \prime}}{X_{d}^{\prime}-X_{d}^{\prime \prime}}+\tau_{d o}^{\prime} S} E_{q}^{\prime \prime}\right.
$$

Excitation system monitors the terminal voltage and provides variable DC current with the desired accuracy. The dynamic performance of the generator is carried out by the excitation system and its model is shown in Fig.4.

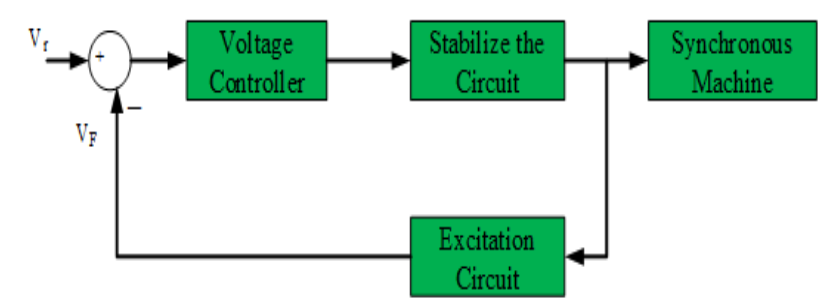

Fig. 4. Diesel Engine Excitation System models [105]

Diesel generator power is based on the fuel consumption and it is represented using Eq.13.

$$
\operatorname{Cons}_{D}=B_{D} \times P_{N}^{D}+A_{D} \times P_{D}
$$

Consumed fuel cost is calculated using Eq.14,

$$
C_{f}=P_{\text {fuel }} \times \text { Cons }_{D}
$$

\section{Electrical Storage System}

Energy saving system is classified based upon the availability of energy as presented in the Fig.5 [35] [36] [37].Most of the classification of energy storage system is described in [38]. These storage systems are used in applications like medicine, transport, electric vehicles, 

duration and it can be classified into three categories as etc. The storage system is selected based on the storage mentioned in Fig.6.

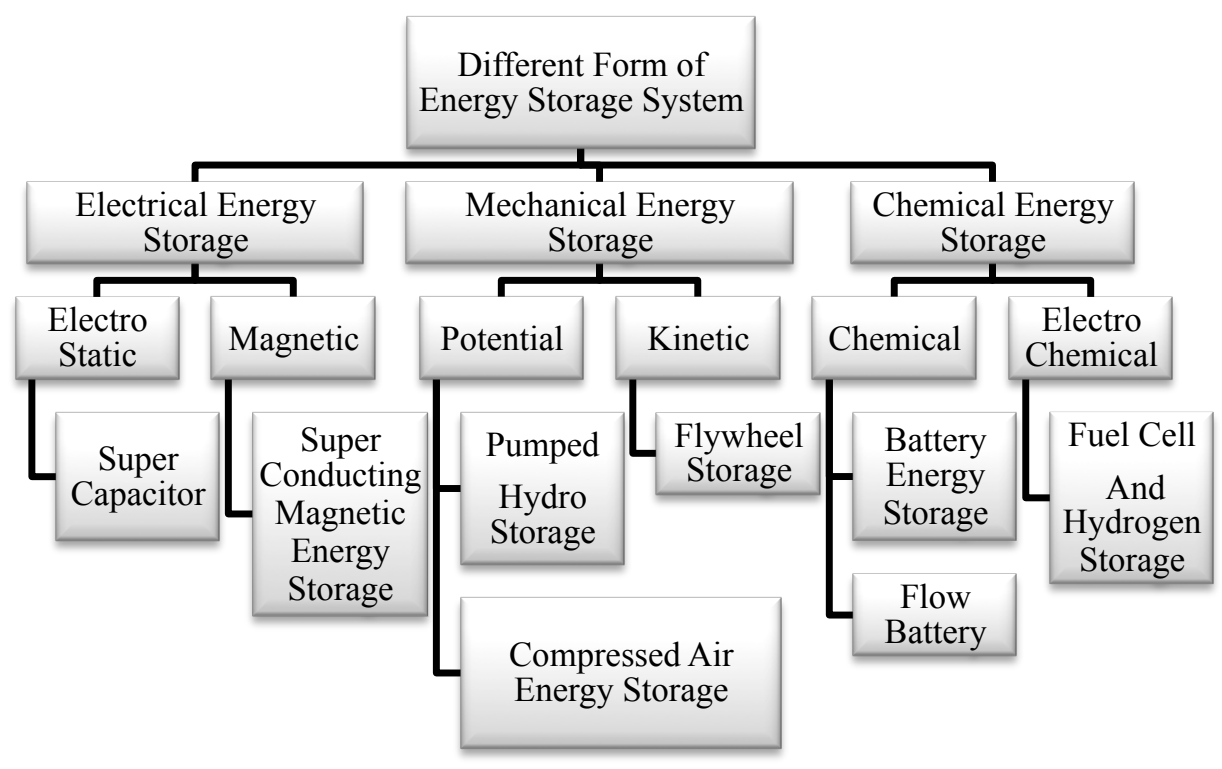

Fig. 5. Different form of energy storage system [36]

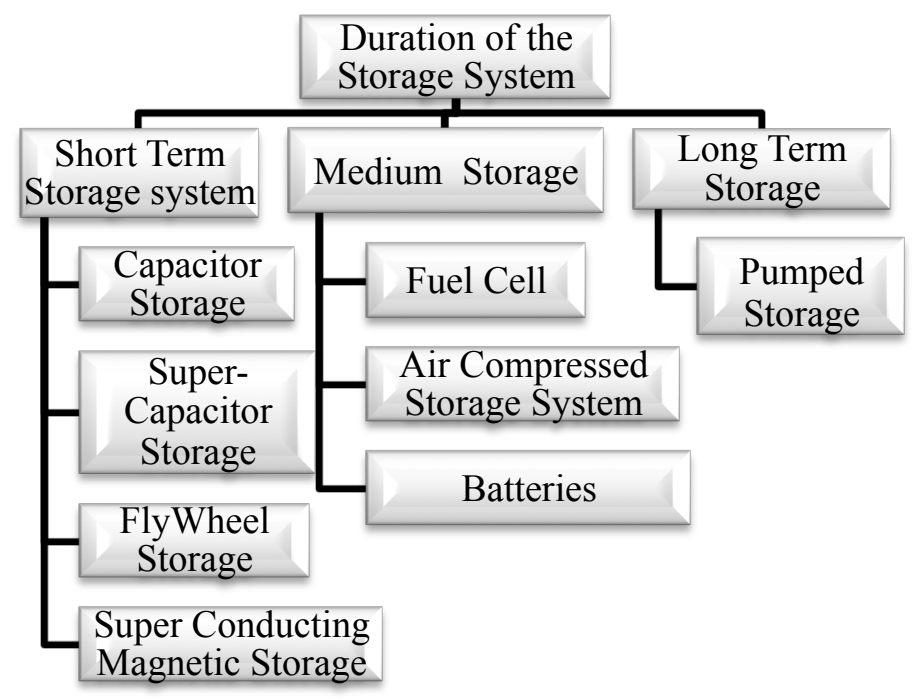

Fig. 6. Classifications of energy storage system based on Duration [35]

Renewable energy systems do not support the peak power requirement and continuous supply. In order to provide sufficient quantity of power for the customer, energy back up is needed. The choice of energy storage device is based on initial state of the charge, lifetime, cost, efficiency and reliability. The objective of the paper [39] is to maintain constant power and suppresses the power fluctuation [40] at the load end.

\section{Battery storage}

Battery storage integrated with hybrid system is to make energy backup and attain the peak demand. Battery stores electricity in the form of chemical energy. Valentin A. Boiceain[41] has focused on various batteries such as LeadAcid, Nickel-metal hydride/Nickel Cadmium, Li-Ion, Sodium-Sulphur, Sodium-Nickel-Chloride $\left(\mathrm{NaNiCl}_{2}\right)$, Inkjet-Printed and Flow batteries. Batteries are preferred based on the state of the charge, depth of discharge, duration of support for energy backup and their capacities. The performance of the batteries and various objectives are mention in Tab.2 [42-80].

\begin{tabular}{l|l|l}
\multicolumn{2}{l}{ Table 2. Types of battery based on the area application and internal chemical reaction } \\
\hline $\begin{array}{c}\text { Name of the battery/ (unit } \\
\text { voltage)/ power density } \\
(\mathrm{W} / \mathrm{Kg})\end{array}$ & \multicolumn{1}{c}{ Chemical reaction } & \multicolumn{1}{c}{ Objective } \\
\hline $\begin{array}{l}\text { Lead Acid battery(2V)/ } \\
(150-300)\end{array}$ & $\begin{array}{l}P b+\mathrm{SO}_{4}^{-2} \leftrightarrow \\
\mathrm{PbSO}_{4}+2 e^{-}\end{array}$ & $\begin{array}{l}\text { Operating condition of the battery and Stress factor is analysed } \\
\text { using Genetic Algorithm combined with weighted Ah model } \\
{[42] .} \\
\text { Applications: Micro grid and Hybrid energy system }\end{array}$ \\
\hline
\end{tabular}




\begin{tabular}{|c|c|c|}
\hline & \multirow{3}{*}{$\begin{array}{l}\mathrm{PbO}_{2}+\mathrm{SO}_{4}^{-2} \\
+4 \mathrm{H}^{+}+2 e^{-} \\
\leftrightarrow \mathrm{PbSO}_{4} \\
+2 \mathrm{H}_{2} \mathrm{O}\end{array}$} & $\begin{array}{l}\text { Reduce technical losses in the distribution system by long term } \\
\text { sizing of the lead acid batter using neural network [43]. } \\
\text { Applications: Distributed Generation(DG) }\end{array}$ \\
\hline & & $\begin{array}{l}\text { Valve regulated lead acid battery model with predictive control is } \\
\text { proposed to charge the battery as fast as possible without } \\
\text { violating the constraint [44]. Applications: Automotive } \\
\text { applications }\end{array}$ \\
\hline & & $\begin{array}{l}\text { Characterize the morphology of Lead-Carbon with composite } \\
\text { electrode [45]. } \\
\text { Applications: Renewable energy sources integration applications }\end{array}$ \\
\hline \multirow[t]{5}{*}{$\begin{array}{l}\text { Lithium-ion battery }(3.7 \mathrm{~V}) / \\
(200-400)\end{array}$} & \multirow[t]{5}{*}{$\begin{array}{l}C+n L i^{+}+n e^{-} \\
\leftrightarrow L i_{n} C\end{array}$} & $\begin{array}{l}\mathrm{LiFe} \mathrm{PO}_{4} \text { Discharging curve is analysed by mathematical model } \\
\text { using dual exponential function closely related to } \mathrm{RC} \text { circuit } \\
\text { characteristics. The state of the charge of the Lithium-ion battery } \\
\text { is modelled [46]. } \\
\text { Applications: Electrical vehicles and Smart grid application }\end{array}$ \\
\hline & & $\begin{array}{l}\text { Focus on impact of negative pulses during the fast charging } \\
\text { process and analyse the performance of battery during static and } \\
\text { dynamic condition [47]. } \\
\text { Applications: Smart grid. }\end{array}$ \\
\hline & & $\begin{array}{l}\text { Economic analysis of } \mathrm{LiFePO}_{4} \text { is performed based on the life time } \\
\text { of the battery with lowest quoting price. Estimates the } \\
\text { requirement of firm frequency response of the U.K Grid [48]. } \\
\text { Applications: National Grid Applications }\end{array}$ \\
\hline & & $\begin{array}{l}\text { Investigation on lifetime and re-establishing the lithium ion } \\
\text { battery state of the charge. Regulates primary frequency response } \\
\text { [49]. } \\
\text { Applications: Grid Applications }\end{array}$ \\
\hline & & $\begin{array}{l}\text { Review on various aspects of Lithium ion battery and their } \\
\text { applications [50]. } \\
\text { Applications: Automotive Applications }\end{array}$ \\
\hline \multirow[t]{2}{*}{$\begin{array}{l}\text { Sodium and Sulphur } \\
(\sim 2.08 \mathrm{~V}) /-\end{array}$} & \multirow[t]{2}{*}{$\begin{array}{l}2 \mathrm{Na} \leftrightarrow \\
2 N a^{+}+2 e^{-}\end{array}$} & $\begin{array}{l}\text { Study on the performance of sodium sulphur batteries with high } \\
\text { doping of sodium and sulphur at room temperature [51]. }\end{array}$ \\
\hline & & $\begin{array}{l}\text { Electronically conducting cathode matrix is proposed to make } \\
\text { excellent discharge performance of sodium-sulphur }(\mathrm{NaS}) \text { battery } \\
\text { [52].Applications: Grid storage application }\end{array}$ \\
\hline $\begin{array}{l}\text { Nickel and Cadmium } \\
(1-1.3 \mathrm{~V}) /(150-200)\end{array}$ & $\begin{array}{l}\mathrm{Cd}+2 \mathrm{OH}^{-} \leftrightarrow \\
\mathrm{Cd}(\mathrm{OH})_{2}+2 e^{-} \\
2 \mathrm{NiOOH}+2 \mathrm{H}_{2} \mathrm{O} \\
+2 e^{-} \leftrightarrow \\
2 \mathrm{Ni}(\mathrm{OH})_{2}+2 \mathrm{OH}^{-}\end{array}$ & $\begin{array}{l}\text { Stability of the nickel cadmium battery is enhanced. } \\
\text { Applications: Solar, wind storage applications[53] }\end{array}$ \\
\hline $\begin{array}{l}\text { Nickel metal hydride } \\
(1-1.3 \mathrm{~V}) /(200-300)\end{array}$ & $\begin{array}{l}\mathrm{H}_{2} \mathrm{O}+e^{-} \leftrightarrow \\
\frac{1}{2} \mathrm{H}_{2}+\mathrm{OH}^{-} \\
\mathrm{Ni}(\mathrm{OH})_{2}+\mathrm{OH}^{-} \\
\leftrightarrow \\
\mathrm{NiOOH}+ \\
\mathrm{H}_{2} \mathrm{O}+e^{-}\end{array}$ & $\begin{array}{l}\text { Stability of the nickel cadmium battery is enhanced. } \\
\text { Applications: Industrial [54] }\end{array}$ \\
\hline \multirow[t]{2}{*}{$\begin{array}{l}\text { Sodium nickel chloride } \\
(\sim 2.58 \mathrm{~V}) /-\end{array}$} & \multirow{2}{*}{$\begin{array}{l}2 \mathrm{Na} \leftrightarrow \\
2 \mathrm{Na}^{+}+2 e^{-} \\
\mathrm{NiCl}_{2}+2 e^{-} \\
\leftrightarrow \mathrm{Ni}+2 \mathrm{Cl}^{-}\end{array}$} & $\begin{array}{l}\text { Analyze the transient operation of Sodium Nickel chloride } \\
\text { batteries [55]. } \\
\text { Applications: Power fluctuation mitigation in renewable energy } \\
\text { source applications }\end{array}$ \\
\hline & & $\begin{array}{l}\text { Analyse the steady state behaviour and modelling of Sodium } \\
\text { Nickel Chloride batteries [56]. } \\
\text { Applications: High Voltage Network Applications }\end{array}$ \\
\hline
\end{tabular}

The batteries are used for various applications such as uninterrupted power supply (UPS), hybrid electric vehicles, and power back up in telecommunication, aerospace and medicine, Industrial solar photovoltaic system and household applications. It is also used for specific applications such as power quality improvement, power management, frequency regulation, peak saving and voltage regulation. Battery storage system is integrated with hybrid generation in both off-grids and on-grid mode to maintain the quality of power at utilities and customer end. Author in 
[57] and [58] has reviewed the internal chemical reaction, capacity, and the applications of various batteries.

\section{Fuel cell}

The promising electrochemical device, which turns chemical energy into electrical energy by reacting positively charged hydrogen ions with the oxygen or other oxidising agents, is called Fuel cell. It consists of three major parts such as fuel, oxidant electrodes (anode/cathode) and an electrolyte squeezed between them. The electrode is covered with a catalyst layer and it is made up of porous material. Based on storage capacity and efficiency different kinds of fuel cell such as alkaline fuel cell, phosphoric acid fuel cell; solid oxide fuel cell, molten carbonate fuel cell; direct methanol fuel cell and proton exchange membrane fuel cells are developed. The authors in[59] [60][61] reviewed and made a comparative study between different kind of fuel cells with respect to their operating temperature, system output, efficiency, chemical reaction, cell voltage, advantages and applications. A comprehensive table has been made to show the complete details of various fuel cell technologies and it is shown in Tab.3. The most prominent fuel cell for hybrid and stand-alone system is PEMFC. This is due to its high efficiency, immediate response, quick start-up time, more life time and less operating temperature. The authors in [80] have demonstrated the PEMFC with precise architecture of metal free cathode which consist of nano particles of carbon and electron acceptor. This architecture controls the electrochemical reaction fuel rate.

Table 3. various types of fuel cell technology

\begin{tabular}{|c|c|c|}
\hline $\begin{array}{c}\text { Name of } \\
\text { the Fuel } \\
\text { cell }\end{array}$ & $\begin{array}{c}\text { Advantages/ } \\
\text { Disadvantages }\end{array}$ & Objectives \\
\hline \multirow[t]{3}{*}{$\begin{array}{l}\text { Alkaline } \\
\text { fuel } \\
\text { cell(AFC) }\end{array}$} & \multirow{3}{*}{$\begin{array}{l}\text { Advantages: } \\
\text { Simple } \\
\text { structure, low } \\
\text { cost catalyst. } \\
\text { Disadvantages: } \\
\text { Easily } \\
\text { contaminated } \\
\text { by } \mathrm{CO}_{2} \\
\text { pure oxygen is } \\
\text { required }\end{array}$} & $\begin{array}{l}\text { Finding the alkaline } \\
\text { stability of quaternary } \\
\text { ammonium cations for AFC } \\
\text { [62]. }\end{array}$ \\
\hline & & $\begin{array}{l}\text { Enhancement of stability of } \\
\text { anion exchange membrane } \\
\text { based imidazolium salt for } \\
\text { alkaline fuel cell [63]. }\end{array}$ \\
\hline & & $\begin{array}{l}\text { Investigation on alkaline } \\
\text { anion exchange membrane } \\
\text { fuel cell [64]. }\end{array}$ \\
\hline \multirow[t]{3}{*}{$\begin{array}{l}\text { Phosphoric } \\
\text { acid fuel } \\
\text { cell(PAFC) }\end{array}$} & \multirow{3}{*}{$\begin{array}{l}\text { Advantages: } \\
\text { Long term } \\
\text { stability } \\
\text { Disadvantages: } \\
\text { initial cost is } \\
\text { high }\end{array}$} & $\begin{array}{l}\text { Maximize the power output } \\
\text { with load matching based } \\
\text { PAFC hybrid system [65]. }\end{array}$ \\
\hline & & $\begin{array}{l}\text { Comprehensive analysis on } \\
\text { PAFC based refrigerator to } \\
\text { recover the waste heat for } \\
\text { cooling purpose [66]. }\end{array}$ \\
\hline & & $\begin{array}{l}\text { The performance of AFC } \\
\text { hybrid system is studied } \\
\text { based on the double } \\
\text { function of PAFC [67]. }\end{array}$ \\
\hline \multirow[t]{2}{*}{$\begin{array}{l}\text { Solid oxide } \\
\text { fuel cell } \\
\text { (SOFC) }\end{array}$} & \multirow{2}{*}{$\begin{array}{l}\text { Advantages: } \\
\text { High thermal } \\
\text { stability, High } \\
\text { chemical } \\
\text { stability, Noise } \\
\text { free. } \\
\text { Disadvantages: }\end{array}$} & $\begin{array}{l}\text { SFOC is integrated with } \\
\text { thermal power plant to } \\
\text { enhance the overall } \\
\text { efficiency [68]. }\end{array}$ \\
\hline & & $\begin{array}{l}\text { Analysis on advancement in } \\
\text { the field of Proton - } \\
\text { conducting electrolytes in }\end{array}$ \\
\hline
\end{tabular}

\begin{tabular}{|c|c|c|}
\hline & \multirow{2}{*}{$\begin{array}{l}\text { long start-up, } \\
\text { cooling down } \\
\text { time }\end{array}$} & SOFC [69]. \\
\hline & & $\begin{array}{l}\text { SOFC is integrated with } \\
\text { Gas Turbine (GT) to } \\
\text { enhance the efficiency of } \\
\text { GT [70]. }\end{array}$ \\
\hline \multirow[t]{3}{*}{$\begin{array}{l}\text { Molten } \\
\text { carbonate } \\
\text { fuel cell } \\
(\mathrm{MCFC})\end{array}$} & \multirow{3}{*}{$\begin{array}{l}\text { Advantages: } \\
\text { Do not require } \\
\text { metal catalyst. } \\
\text { infrastructure } \\
\text { is not required } \\
\text { for } \\
\text { development } \\
\text { Disadvantages: } \\
\text { takes long time } \\
\text { to operate and } \\
\text { generate power }\end{array}$} & $\begin{array}{l}\text { Performance analysis of } \\
\text { Irreversible MCFC -Brays } \\
\text { on heat engine is studied } \\
\text { with respect to thermo } \\
\text { dynamic parameter [71]. }\end{array}$ \\
\hline & & $\begin{array}{l}\text { Design and analysis of } \\
\text { integrated MCFC system } \\
\text { in marine applications [72] }\end{array}$ \\
\hline & & $\begin{array}{l}\text { Review on current status of } \\
\text { MCFC life cycle } \\
\text { assessment [73] }\end{array}$ \\
\hline \multirow[t]{2}{*}{$\begin{array}{l}\text { Direct } \\
\text { methanol } \\
\text { fuel cell } \\
\text { (DMFC) }\end{array}$} & \multirow{2}{*}{$\begin{array}{l}\text { Advantages: } \\
\text { Can operate at } \\
\text { low } \\
\text { temperature, } \\
\text { longer life, no } \\
\text { need to charge } \\
\text { Disadvantages: } \\
\text { Fuel } \\
\text { vaporization at } \\
\text { high } \\
\text { temperature. }\end{array}$} & $\begin{array}{l}\text { Performance study of } \\
\text { DMFC based on the fuel } \\
\text { consumption } \\
\text { temperature [74]. }\end{array}$ \\
\hline & & $\begin{array}{l}\text { Performance of flowing } \\
\text { electrodes in DMFC to } \\
\text { reduce the methanol } \\
\text { crossover [75]. } \\
\text { The performance of Poly } \\
\text { (vinyl alcohol) based } \\
\text { composite membrane with } \\
\text { phosphotungstic acid } \\
\text { molecules is studied for } \\
\text { DMFC applications [76]. }\end{array}$ \\
\hline \multirow{3}{*}{$\begin{array}{l}\text { Proton } \\
\text { exchange } \\
\text { membrane } \\
\text { fuel cell } \\
\text { (PEMFC) }\end{array}$} & \multirow{3}{*}{$\begin{array}{l}\text { Advantages: } \\
\text { Fast start-up, } \\
\text { High power } \\
\text { density, } \\
\text { Longer life, } \\
\text { Low } \\
\text { temperature. } \\
\text { Disadvantages: } \\
\text { Minimum } \\
\text { maintenance is } \\
\text { required }\end{array}$} & $\begin{array}{l}\text { Author has reviewed on } \\
\text { recent advances and } \\
\text { challenges on PMFC [77]. }\end{array}$ \\
\hline & & $\begin{array}{l}\text { Micro structural analysis of } \\
\text { PMFC electrodes is } \\
\text { performed [78]. }\end{array}$ \\
\hline & & $\begin{array}{lr}\text { PFMC based } & \text { power } \\
\text { conversion } & \text { system } \\
\text { proposed with genetic } \\
\text { algorithm for supplying } \\
\text { power } \\
\text { telecommunication towers } \\
{[79] \text {. }}\end{array}$ \\
\hline
\end{tabular}

The authors have also suggested PEMFC based on precious metal free cathode which leads to the delivery of $154 \mathrm{~mW} / \mathrm{cm}^{2}$ power at $358 \mathrm{~mA} / \mathrm{cm}^{2}$ current. Marcello Baricco et al. [81] designed the fuel cell coupled with solid state hydrogen storage tank. The main intension of this project is to develop the hydrogen fuel based auxiliary power unit installed on a light duty commercial vehicle.

\section{Hydrogen Storage System}

The hydrogen is a clean and efficient fuel which is used in energy saving for hybrid generation to meet the necessary power. There are two possibilities for production of Hydrogen i.e. from non-renewable and renewable energy sources. In this paper, the focus is on the renewable energy based hydrogen production due to economy and less greenhouse gas emission. Primary sources for electricity generation, hydrogen production and storage system are shown in Fig.7 [82] [83]. The production of hydrogen can be taken through the electrolysis process from the renewable 
sources. The advance development of hydrogen storage technology is with respect to materials and methods such as chemical storage, Physisorption and compressed storage, liquid hydrogen. In Chemical storage method, hydrogen is stored through chemical reaction process using different materials such as Ammonia, metal hydrides, formic acid, carbohydrate, and liquid organic hydrogen carriers.

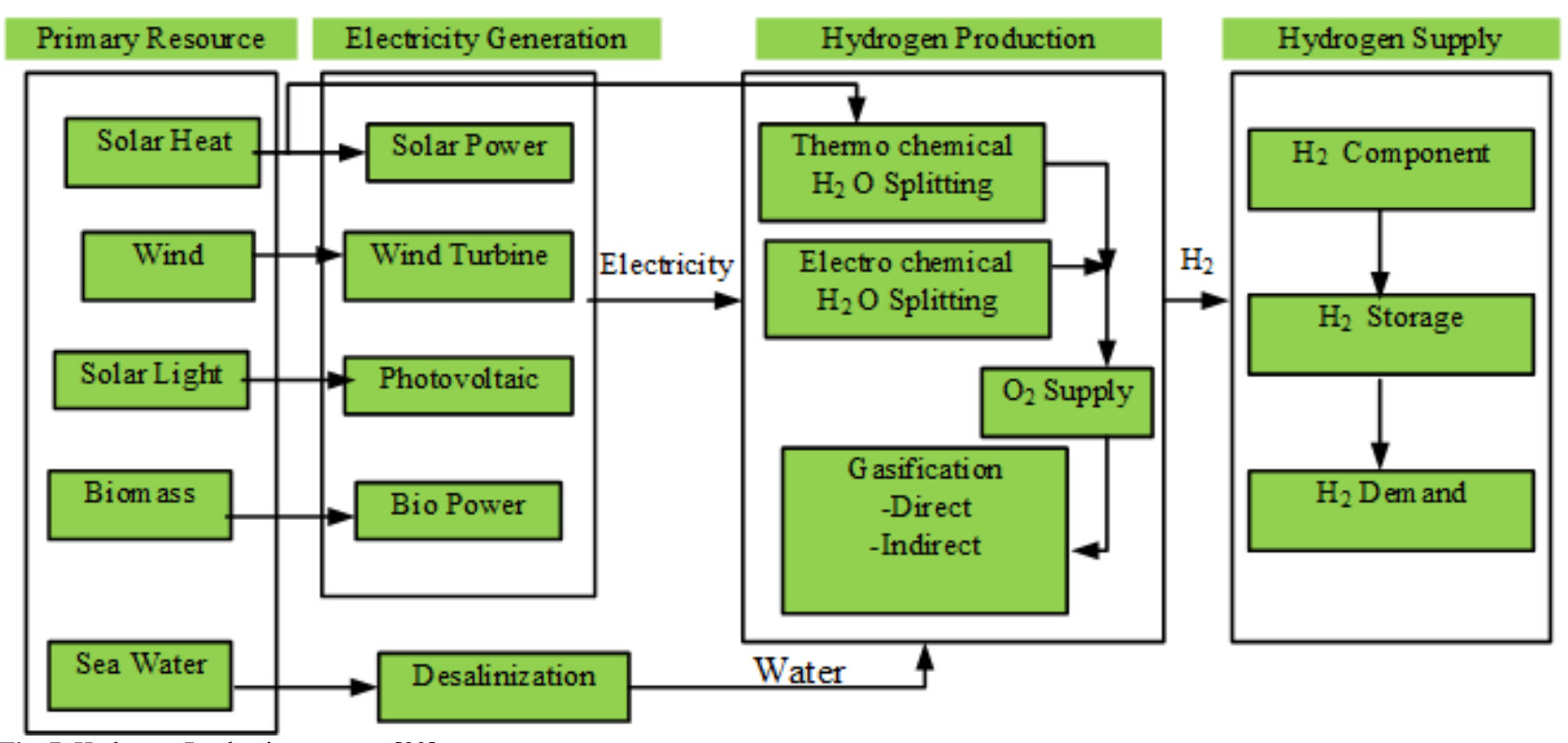

Fig. 7. Hydrogen Production systems [83]

In physisorption method, the kinetics involved in storage process of hydrogen is possible by maintaining the molecular identity of Hydrogen. In compressed storage method, hydrogen gas is stored in the high pressure tank physically. Liquid hydrogen requires cryogenic storage and it can store $0.070 \mathrm{~kg} / \mathrm{Lof}$ liquid hydrogen. A comparative study of Hydrogen storage methods based on various parameters like gravimetric capacity, volumetric capacity, temperature, pressure, system cost, method of storage, benefits with limitation is presented in [84].

\section{Hybrid system}

The integration of the multi renewable energy system is called hybrid system. The modelling of hybrid renewable energy sources is becoming prominent and popular in remote areas [85] and plays a major role in the distribution system. Optimal sizing [86] with artificial intelligent techniques [87] of the hybrid system can meet the load demand with less financial investment. The basic details of the hybrid system, modules of solar-wind-diesel with an energy storage system are briefly discussed in the following section. The basic diagram of hybrid system with energy storage is shown in Fig.8.The hybrid system consists of renewable/non-renewable sources, bi-directional and different type of AC/DC converters. It also consists of DCbus and AC-bus configuration with different sources and load connection.

In a hybrid system, renewable energy sources are considered as the primary sources while the non-renewable sources are connected as a backup or directly to the load. The storage system can be used as energy back up and also to meet the peak demand. If excessive power is generated from the renewable energy sources, it can be stored in the storage system or injected into the grid with the help of grid control unit and energy management system.Fig.8 is shown with an assumption that the hybrid system is capable to supply the load without taking power from the grid. The hybrid renewable energy integration can be operated in two different modes, namely standalone and grid connected mode. According to the load demand and the geographical location, these hybrid systems are operated indifferent mode.

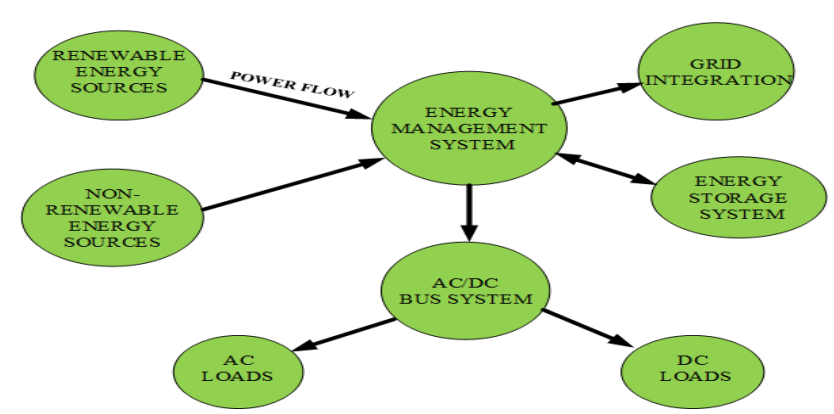

Fig. 8. Schematic Diagram of hybrid system with Energy storage

The authors in [88] have implemented real-time integration of solar PV-wind-battery hybrid system to solve the challenges with respect to the dynamic variation of load consumption. Integration of solar photovoltaic (PV)-wind with energy storage and management system with optimizing model is discussed in [89]. The authors in [90] propose static compensator in the integration of solar PVwind-Diesel engine hybrid system with intelligent control. In this paper, Elman neural method is applied to capture the maximum power from wind and radial basis function method is used to analyse and track the maximum power from the solar PV. This hybrid system provides reactive power with quick stabilized retorts.

Various means of cost savings, reduction in environmental pollution and comparison between different energy systems like solar PV, wind, diesel is carried out in 
[91] and for the same hybrid system, TaherMaatallahet. al. [92] has investigated on optimizing the overall cost of the system with and without battery. In [93], the authors investigate grid connected hybrid system for household applications to track the maximum power from the hybrid sources. They have also discussed the importance of transformer-coupled boost half bridge converter and full bridge bidirectional converter for the same application. Integration of hybrid system with diesel in the AC bus system without any storage is considered [94] to regulate the dynamic variation in frequency. Adaptive-predictorcorrector-based Neuro-fuzzy controller is proposed to regulate the output of photovoltaic generator for frequency regulation. The frequency and inertia control [95] techniques are performed in the hybrid system.

The extension of grid for rural area is cost expensive and may not provide flexible power with the existing power system. The off-grid system provides flexible power for remote areas to meet the power demand. The performance of stand-alone hybrid renewable energy sources with diesel and battery storage using an optimized heuristic algorithm is suggested in [96].The optimized net present cost(NPC), reduction of $\mathrm{CO}_{2}$ emission and greenhouse gas emission is deployed under renewable energy environment [97][98]. The authors also explain how the hybrid system is eco-friendly with the environment compared to the conventional power plant. The integration of standalone hybrid energy system is most economical and fuel-saving with maximum utilization of full load capacity of $80-100 \%$ [99]. The off-grid hybrid system with different battery technologies using genetic algorithm is discussed to achieve the system reliability [100]. Rajanna Siddaiah and R.P.Saini [101] reviewed the application of different optimization/intelligent techniques on modelling the hybrid system such as Genetic Algorithm, Artificial Neural Network and Particle Swarm Optimization.

The authors have compared AC and DC off-grid hybrid system, and discussed on various cost functions such as to minimize the levelized cost of energy, total life cycle cost, total net present cost models which are used in the hybrid system. The selection of various off-grids coupled configuration [102] can be estimated depends on the application. The advantage and disadvantage of off-grid AC and DC coupled configuration is shown in Tab.4. Akbar Maliki and Fathollah Porfayaz [103] has proposed the integration of solar PV-wind-Diesel with storage devices such as battery and fuel cell, and comparison is made with traditional integration of solar PV-wind-diesel hybrid system based on the modelling, sizing and cost analysis. The importance of using a small split diesel generator instead of a large diesel generator for a typical residential building is discussed lucidly in [104].Sana Charfi et al. [105] have taken the power generation from three different countries, namely the Kingdom of Saudi Arabia, Tunisia and Jordan on which a complete investigation on its total investment is carried out. Diesel, PV-battery storage bank and hybrid PVDiesel engine-battery bank modelling and cost analysis are done. It is identified that the Kingdom of Saudi Arabia maintains the efficient hybrid system compared to the other two countries in terms of cost and pollution.

From the comparison made in Tab.4, it is found that DC bus configuration is highly reliable and simple in terms of design and cost. And hence DC configuration is taken for further discussion in the remaining part of the paper. DC configured hybrid system consists of solar PV, Wind generation, Diesel generator, Battery, Fuel cell, Hydrogen storage tank, Electrolyzer, control units and converters which are illustrated in Fig.9. The solar PV and wind sources are the primary input for supplying required power and peak load. Excessive power is drawn from the storage devices, such as battery and hydrogen storage system.

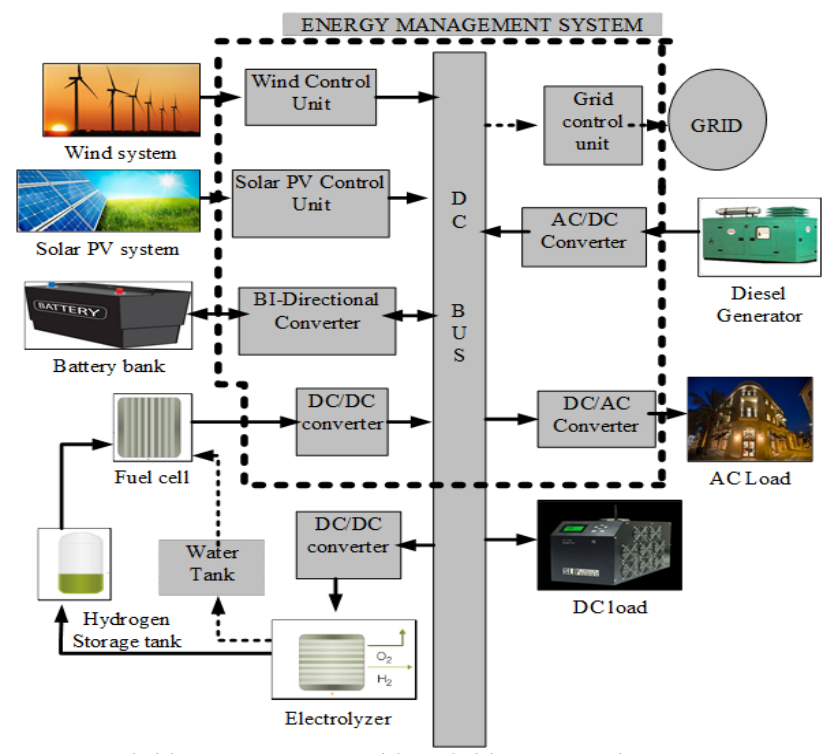

Fig. 9. Hybrid energy systems with Hybrid storage units

Table 4. Comparison of different off-grid AC and DC bus system

\begin{tabular}{c|c}
$\begin{array}{c}\text { Type of } \\
\text { coupled } \\
\text { Configuration }\end{array}$ & Advantage/ Disadvantage \\
\hline & \\
\hline
\end{tabular}

\begin{tabular}{l|l}
$\begin{array}{l}\text { DC-bus } \\
\text { system }\end{array}$ & $\begin{array}{l}\text { Advantage: No } \\
\text { configuration } \\
\text { required. } \\
\text { Disadvantage: Unable to supply AC loads } \\
\text { when DC/AC converter fails. } \\
\text { sdvantage: Good for remote area } \\
\text { applications. }\end{array}$ \\
$\begin{array}{l}\text { Power } \\
\text { Frequency } \\
\text { AC- bus } \\
\text { system }\end{array}$ & $\begin{array}{l}\text { unit for AC bus system to extract power } \\
\text { from renewable energy sources } \\
\text { Advantage: High efficiency with less cost. }\end{array}$ \\
$\begin{array}{l}\text { Hybrid } \\
\text { configuration }\end{array}$ & $\begin{array}{l}\text { Disadvantage: Complexity in control and } \\
\text { management in both AC\&DC bus system } \\
\text { Advantage: Favourable for rural area with } \\
\text { enhanced capacity and fuel saving. } \\
\text { Disadvantage: Causes environment } \\
\text { Diesel, Hybrid } \\
\text { pollution and complex in control. }\end{array}$ \\
\hline
\end{tabular}

It is found that the following strategies can be adapted under different combination of available energy sources.

- In the absence of sunlight and during the transient period, the load demand can be met by the supply of wind-diesel generator and storage system.

- If the wind fails to supply, then the power can be supplied from solar PV-diesel with an energy storage system and vice versa.

- If wind and solar PV fails, then diesel generator and storage system can supply the power with the help of energy management control scheme.

- The excessive power from the prime input can be stored and injected into the grid with the help of grid 
synchronizing unit and energy management control scheme.

\section{Sizing Methodology of Hybrid System:}

Sizing methodology of hybrid system are classified into different types based on the design and level of complexity such as probabilistic, analytical, iterative and hybrid methods. Probabilistic method is used for finding one or two system based performance indices like Loss of Power Supply Probability (LPSP), Levelized Cost of Energy (LCE), Level of Autonomy (LA), Net Present Value, Annualized Cost of System (ACS), Expected Energy Not Supplied (EENS) and Battery State of the Charge (SOC). Analytical method is used to examine the single or multiple performances of the indices on hybrid system. In this method, results are obtained by computational method using simulation tool like HOMER.

Table 5. Objective, constraints and techniques used in Hybrid system

\begin{tabular}{|c|c|c|}
\hline Constraints & $\begin{array}{c}\text { Tool/Techniqu } \\
\text { e } \\
\end{array}$ & Objectives \\
\hline $\begin{array}{l}\text { Minimize the } \\
\text { levelized cost of } \\
\text { energy and LPSP }\end{array}$ & $\begin{array}{l}\text { Hybrid } \\
\text { Optimization } \\
\text { Of Multiple } \\
\text { Energy } \\
\text { Sources(HOME } \\
\text { R) }\end{array}$ & $\begin{array}{lr}\text { To } & \text { achieve } \\
\text { minimum } & \text { cost of } \\
\text { energy } & \text { with } \\
\text { require } & \text { load } \\
\text { demand } & \text { using } \\
\text { hybrid } & \text { system } \\
{[107] .} & \end{array}$ \\
\hline $\begin{array}{l}\text { Cost of Energy } \\
\text { (COE), Net Present } \\
\text { Cost (NPC) }\end{array}$ & HOMER & $\begin{array}{l}\text { Optimize the } \\
\text { result with } \\
\text { minimum COE, } \\
\text { NPC and } \\
\text { renewable fraction } \\
\text { of } 41.6 \% \text { [108]. }\end{array}$ \\
\hline $\begin{array}{l}\text { Total net present } \\
\text { cost }\end{array}$ & HOMER & $\begin{array}{l}\text { To design a hybrid } \\
\text { system at Ouled } \\
\text { Fares, and } \\
\text { Mouafkia in Chief } \\
\text { at Algeria [109]. }\end{array}$ \\
\hline COE, NPC & HOMER & $\begin{array}{l}\text { Hybrid system } \\
\text { simulation with } \\
\text { three different } \\
\text { diesel prices per } \\
\text { litre [110]. }\end{array}$ \\
\hline $\begin{array}{l}\text { loss of power } \\
\text { supply probability } \\
\text { (LPSP) }\end{array}$ & $\begin{array}{l}\text { Genetic } \\
\text { Algorithm(GA) }\end{array}$ & $\begin{array}{lr}\text { To attain } \\
\text { minimum desired } \\
\text { loss of power } \\
\text { supply probability } \\
\text { with r battery } \\
\text { saving space } \\
\text { capacity [111]. }\end{array}$ \\
\hline $\begin{array}{l}\text { Cost of energy and } \\
\text { State of charge }\end{array}$ & $\begin{array}{l}\text { Guaranteed } \\
\text { convergence } \\
\text { PSO with } \\
\text { Gaussian } \\
\text { mutation }\end{array}$ & $\begin{array}{l}\text { To optimize the } \\
\text { cost invested in } \\
\text { the form of fuel } \\
\text { and initial } \\
\text { investment on a } \\
\text { hybrid system } \\
{[112] .}\end{array}$ \\
\hline $\begin{array}{l}\text { Cost } / \mathrm{kWh} \text {, level of } \\
\text { autonomy }\end{array}$ & $\begin{array}{l}\text { Particle Swarm } \\
\text { Optimization } \\
\text { (PSO) }\end{array}$ & $\begin{array}{l}\text { To improve the } \\
\text { performance in } \\
\text { terms of overall } \\
\text { cost [113]. }\end{array}$ \\
\hline Total operating cost & Optimization & The hybrid PV- \\
\hline
\end{tabular}

using Genetic Algorithm

Net present cost (NPC)

Stochastic method

Minimize the Total Cost

LPSP and cost analysis

\section{Cost of \\ Electricity(COE),T otal Net Present Cost (TNPC) COE, NPC

Net present cost \\ (NPC), $\mathrm{COE}$}

Multi object particle swarm optimization

\section{COE, Operating \\ Life Cycle(OLC), LPSP}

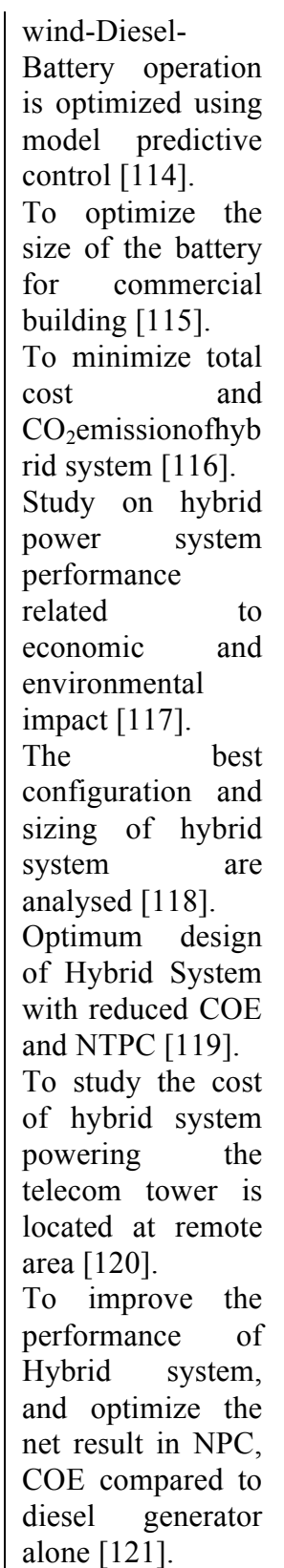

In Iterative method, optimized results are obtained by recursive process. This method is applied for optimization of reliability and total cost involved in integrated renewable energy system. The authors in [106] have made review on sizing methodology of hybrid energy system. Tab.5 shows the objectives framed by different authors with different constraints $[107-121]$.

\section{Power Management in Hybrid system}

Providing necessary power to the load continuously by managing the multiple source and state of the energy storage system is termed as power management system. The author in [122] has presented power management in standalone wind-photovoltaic-fuel cell Hybrid system. The overall power management and control strategy for a hybrid system block diagram is shown in Fig.10. Net power is calculated based on the power difference between total power generation by the multiple sources and load.

$P_{\text {Net }}=P_{p v}+P_{\text {wind }}-P_{\text {load }}-P_{S C}-P_{\text {comp }}$ 
At any time if solar $\mathrm{PV}$, wind is generated excessive power $\left(\mathrm{P}_{\mathrm{Net}}>0\right)$ then the excessive power is transfer to the electrolyzer and it can be further stored in hydrogen storage tank through the gas compressor. Gas compressor also consumes the power $\left(\mathrm{P}_{\text {comp }}\right)$. The power balance equation can be represented in Eq. 16.

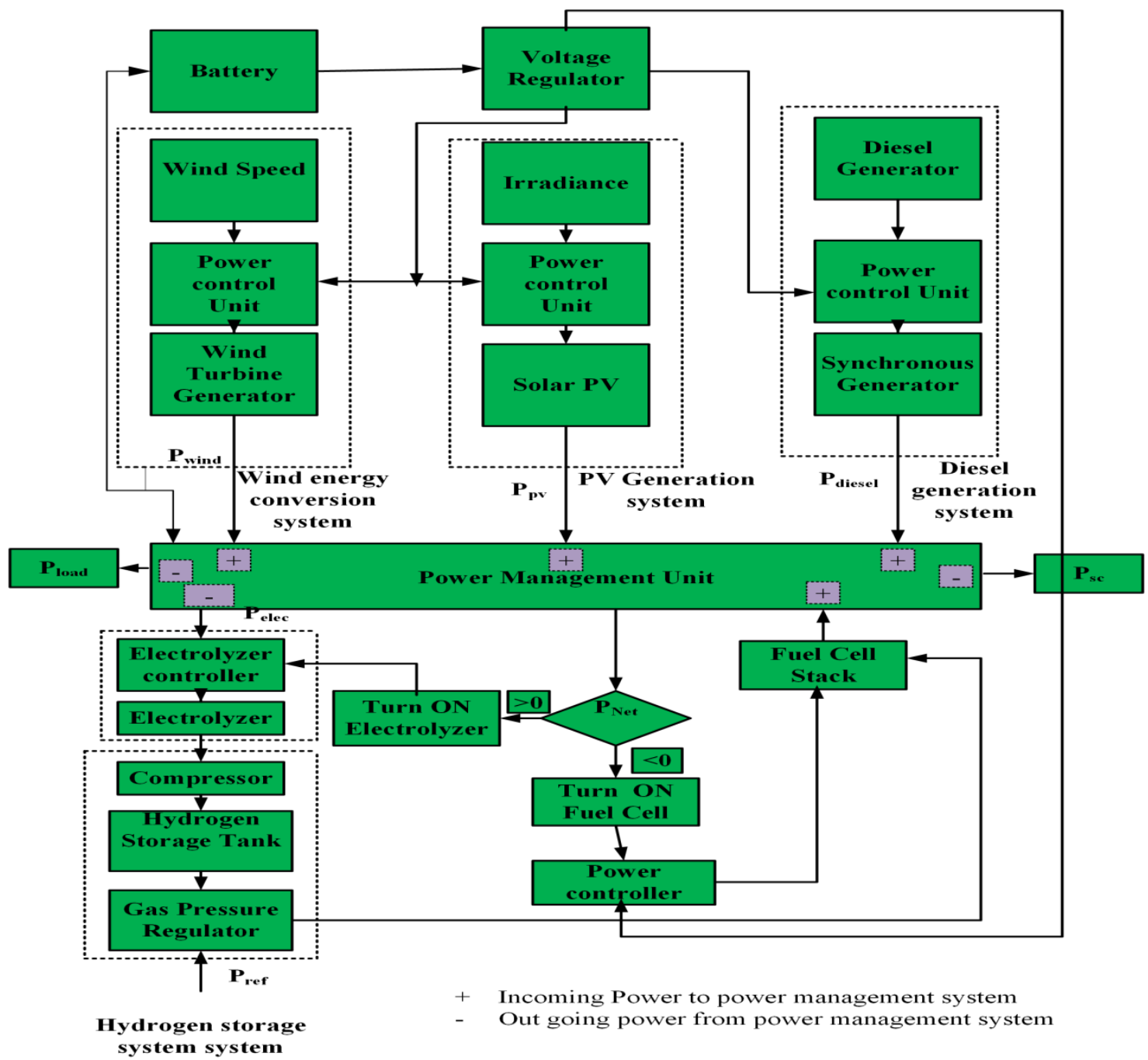

Fig. 10. Power Management in Hybrid system

$P_{p v}+P_{\text {wind }}=P_{\text {load }}+P_{S C}+P_{\text {comp }}$

The power supply from the wind-PV is less than the load demand then the power can be supplied from the Fuel cell and diesel generator. The power is shortages exist at any time then the power balance is obtained from Eq.17.

$P_{\text {load }}=P_{\text {wind }}+P_{p v}+P_{\text {diesel }}+P_{F C}$

The power management is quit complex in hybrid system. Erkan Dursun and Osman Kilic [123] has explained and simulated hybrid system with power management scheme. The power management in hybrid system can be categorized into three different cases. In the first case, if $\mathrm{P}_{\text {excess }}>0$ and state of the charge $\left(\mathrm{SOC}_{\max }\right)>\mathrm{SOC}>\mathrm{SOC}_{\min }$ then the battery will be discharge and electrolyzer will contributes the power. In second case, If $\mathrm{P}_{\text {excess }} \leq 0$, $\mathrm{SOC}_{\max }>\mathrm{SOC}>\mathrm{SOC}_{\min }$, then the power battery bank will discharge and fuel cell will not run. Battery bank is charged when $\mathrm{SOC} \leq \mathrm{SOC}_{\min }$ and $\mathrm{P}_{\text {excess }} \leq 0$.in this case the fuel cell will run. In the third case, $\mathrm{P}_{\text {excess }}>0, \mathrm{SOC}_{\max }>\mathrm{SOC}>\mathrm{SOC}_{\min }$ the battery will be charge and electrolyzer also work for providing continuous supply. At $\mathrm{P}_{\text {excess }}<0$, the battery and fuel cell are not run to meet the peak demand then the diesel generator will work for continuity supply. The mathematical power balance equation can be calculated using the following Eq.18.

$P_{\text {load }}+P_{\text {comp }}+P_{\text {load }}=P_{\text {wind }}+P_{p v}+P_{\text {diesel }}$

The smart energy management algorithm are balance the electrical demand with source, Improve the grid reliability, Schedule the dispatch of hybrid sources. The combination of solar PV, wind, diesel, Fuel cell, and Battery storage based hybrid system are becoming popular the author in [124] has studied for different plant with different cities in India such as Amritsar, Ludhiana, Patiala, and Chandigarh in Punjab. The authors has found best solution for the cost of energy for respective cities with load of $1.3 \mathrm{~kW}$ peak is PV-WindDiesel-Battery storage system are useful. The challenging research is going on the hybrid system to meet the load demand continuously with less investment and more 


\section{Ravi Dharavath, I. Jacob Raglend, S. Prabhakar Karthikeyan and J. Belwin Edward./}

\section{Journal of Engineering Science and Technology Review 11 (5) (2018) 61 - 75}

reliable. The ministry of new renewable energy (MNRE) government is planned for hybrid system with the capacity of $10 \mathrm{GW}$ by 2022 [125].

\section{Conclusions}

In this paper, a review on optimal sizing, modelling, control and management of solar-wind-diesel with the energy storage system are presented. The various issues on solar, wind and control technique are also compared. The selection of various configurations in hybrid and storage system improves the performance of the system. Integration of hybrid systems with an energy storage system makes the power balance and can avoid power fluctuation during the dynamic variations in the environment. The importance of solar-wind with diesel, energy storage integration creates benefit in solving the power crisis issues in remote locations.

This is an Open Access article distributed under the terms of the Creative Commons Attribution Licence

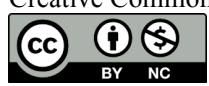

\section{References}

1. Khare V, Nema S, Baredar P, 'Solar-wind hybrid renewable energy system: A review,' Renewable and Sustainable Energy Reviews. vol58, pp.23-33(2016)

2. https://en.wikipedia.org/wiki/Electricity_sector_in_India\#History

3. http://vidyutpravah.in/

4. Tripathi L, Mishra AK, Dubey AK, Tripathi CB, Baredar P, 'An overview on its contribution in current energy scenario of India', Renewable and Sustainable Energy Reviews. Vol 60, pp.22633(2016)

5. http://www.renewableenergyfocus.com/view/20968/world-energyuse-up-53-by-2035

6. Adewuyi AO, Awodumi OB, 'Renewable and non-renewable energy-growth-emissions linkages: Review of emerging trends with policy implications', Renewable and Sustainable Energy Reviews, vol69.275-91.

7. Dong J, Xue G, Dong M, Xu X, ' Energy-saving power generation dispatching in China: Regulations, pilot projects and policy recommendations-A review', Renewable and Sustainable Energy Reviews, vol 43, pp.1285-300(2015).

8. Bélaïd F, Youssef M. 'Environmental degradation, renewable and non-renewable electricity consumption, and economic growth: Assessing the evidence from Algeria', Energy Policy, Vol 102, pp.277-87(2017).

9. Gasparatos A, Doll CN, Esteban M, Ahmed A, Olang TA, 'Renewable energy and biodiversity: Implications for transitioning to a Green Economy', Renewable and Sustainable Energy Reviews',vol 70,pp:161-84, (2017)

10. Murray C, Platzer W, Petersen J,'Potential for solar thermal energy in the heap bioleaching of chalcopyrite in Chilean copper mining',Minerals Engineering, vol 100, pp.75-82(2017)

11. Aliari Y, Haghani A, 'Planning for integration of wind power capacity in power generation using stochastic optimization'Renewable and Sustainable Energy Reviews, vol 59, pp.907-19(2016).

12. Rezzouk H, Mellit A, 'Feasibility study and sensitivity analysis of a stand-alone photovoltaic-diesel-battery hybrid energy system in the north of Algeria', Renewable and Sustainable Energy Reviews, vol 43, pp.1134-50(2015).

13. Musunuri S, Ginn HL, 'A comprehensive review of wind energy maximum power extraction algorithms', IEEE power and energy society general meeting,vol 24, pp. 1-8(2011).

14. Khan J, Arsalan MH,'Solar power technologies for sustainable electricity generation-A review',Renewable and Sustainable Energy Reviews, vol 55, pp.414-25(2016).

15. Inganäs $\mathrm{O}$, Sundström $\mathrm{V}$, 'Solar energy for electricity and fuels',Ambio, vol 45, pp:15-23(2016).

16. Villalva MG, Gazoli JR, RuppertFilho E, 'Comprehensive approach to modeling and simulation of photovoltaic arrays',IEEE Transactions on power electronics, vol 5, pp.1198-208(2009).

17. Mohammed YS, Mustafa MW, Bashir N, Ibrahem IS, 'Existing and recommended renewable and sustainable energy development in Nigeria based on autonomous energy and microgrid technologies', Renewable and Sustainable Energy Reviews(2016 )

18. Manju S, Sagar N, 'Progressing towards the development of sustainable energy: A critical review of the current status, applications, developmental barriers and prospects of solar photovoltaic systems in India', Renewable and Sustainable Energy Reviews, vol70, pp.298-313(2017).
19. Madeti SR, Singh SN, 'Monitoring system for photovoltaic plants: A review', Renewable and Sustainable Energy Reviews, vol 67, pp.1180-207(2017).

20. Ozoegwu CG, Mgbemene CA, Ozor PA, 'The status of solar energy integration and policy in Nigeria', Renewable and Sustainable Energy Review, vol 70, pp.457-71(2017).

21. VermaD,Nema S, Shandilya AM, Dash SK, 'Maximum power point tracking (MPPT) techniques: Recapitulation in solar photovoltaic systems', Renewable and Sustainable Energy Reviews, vol 54, pp.1018-34(2016).

22. Saravanan S, Babu NR, 'Maximum power point tracking algorithms for photovoltaic system-A review', Renewable and Sustainable Energy Reviews, vol57, pp.192-204(2016).

23. Das M, Agarwal V, 'Novel High-Performance Stand-Alone Solar PV System with High-Gain High-Efficiency DC-DC Converter Power Stages' IEEE Transactions on Industry Applications, Vol 6, pp.4718-28(2015).

24. Tsengenes $G$, Adamidis $G$, 'Investigation of the behaviour of a three-phase grid-connected photovoltaic system to control active and reactive power', Electric Power Systems Research. , vol1, pp.177-84(2011).

25. Emmanuel M, Rayudu R, 'Evolution of dispatch able photovoltaic system integration with the electric power network for smart grid applications: A review',Renewable and Sustainable Energy Reviews,vol 67, pp.207-24(2017).

26. Murray C, Platzer W, Petersen J, 'Potential for solar thermal energy in the heap bioleaching of chalcopyrite in Chilean copper mining',Minerals Engineering, vol 100, pp.75-82(2017).

27. Shezan SA, Julai S, Kibria MA, Ullah KR, Saidur R, Chong WT, Akikur RK, 'Performance analysis of an off-grid wind-PV (photovoltaic)-diesel-battery hybrid energy system feasible for remote areas', Journal of Cleaner Production, vol 125, pp.12132(2016).

28. Maleki A, Askarzadeh A, 'Artificial bee swarm optimization for optimum sizing of a stand-alone PV/WT/FC hybrid system considering LPSP concept',Solar Energy,vol 107, pp.22735(2014).

29. Musunuri S, Ginn HL, 'A comprehensive review of wind energy maximum power extraction algorithms', IEEE power and energy society general meeting, pp. 1-8(2011)

30. Aliari Y, Haghani A, 'Planning for integration of wind power capacity in power generation using stochastic optimization', Renewable and Sustainable Energy Reviews, vol 59, pp.90719(2016).

31. Abdullah MA, Yatim AH, Tan CW, Saidur R, 'A review of maximum power point tracking algorithms for wind energy system', Renewable and sustainable energy reviews, vol 16(5), pp.3220-7(2012)

32. Kusakana K, 'Optimal scheduled power flow for distributed photovoltaic/wind/diesel generators with battery storage system',IET Renewable Power Generation,vol 9(8) , pp.91624(2015).

33. Rozali NE, Alwi SR, Ho WS, Manan ZA, Klemeš JJ, 'Integration of diesel plant into a hybrid power system using power pinch analysis',Applied Thermal Engineering(2016).

34. Pathak G, Singh B, Panigrahi BK, 'Back propagation algorithm based controller for theautonomous wind-DG microgrid',InPower India, International Conference (PIICON), $20146^{\text {th }} I E E E$, pp.1-5(2014)

35. Chauhan A, Saini RP, 'A review of integrated renewable energy system based power generation for stand-alone applications: 


\section{Ravi Dharavath, I. Jacob Raglend, S. Prabhakar Karthikeyan and J. Belwin Edward./}

\section{Journal of Engineering Science and Technology Review 11 (5) (2018) 61 - 75}

configurations, storage options, sizing methodologies and control',Renewable and Sustainable Energy Reviews, vol 38, pp.99-120(2014)

36. Hemmati R, Saboori H, 'Emergence of hybrid energy storage systems in renewable energy and transport applications-A review',Renewable and Sustainable Energy Reviews, vol 65, pp.11-23(2016).

37. Gallo AB, Simões-Moreira JR, Costa HK, Santos MM, dos Santos EM, 'Energy storage in the energy transition context: A technology review',Renewable and Sustainable Energy Reviews,vol 65, pp.800-22(2016).

38. Guney MS, Tepe Y, 'Classification and assessment of energy storage systems',Renewable and Sustainable Energy Reviews(2016).

39. Liu Y, Du W, Xiao L, Wang H, Bu S, Cao J, 'Sizing a Hybrid Energy Storage System for Maintaining Power Balance of an Isolated System With High Penetration of Wind Generation', IEEE Transactions on Power Systems, vol (4) , pp.326775(2016).

40. Jiang W, Zhang L, Zhao H, Huang H, Hu R, 'Research on power sharing strategy of hybrid energy storage system in photovoltaic power station based on multi-objective optimisation',IET Renewable Power Generation,vol 10(5), pp.575-83(2016).

41. Boicea VA, 'Energy storage technologies: The past and the present. Proceedings of the IEEE vol 102(11), pp.1777-94(2014).

42. Luo X, Wang J, Dooner M, Clarke J, 'Overview of current development in electrical energy storage technologies and the application potential in power system operation',Applied Energy,vol 137, pp.511-36(2015).

43. Akinyele DO, Rayudu RK, 'Review of energy storage technologies for sustainable power networks,Sustainable Energy Technologies and Assessments, vol 8, pp.74-91(2014)

44. Lujano-Rojas JM, Dufo-López R, Atencio-Guerra JL, Rodrigues EM, Bernal-Agustín JL, Catalão JP, 'Operating conditions of lead-acid batteries in the optimization of hybrid energy systems and microgrids',Applied Energy,vol 179, pp.590-600(2016).

45. Monteiro RV, Guimarães GC, Moura FA, Albertini MR, Silva FB. Long-term sizing of lead-acid batteries in order to reduce technical losses on distribution networks: A distributed generation approach. Electric Power Systems Research. 2017 Mar 31; vol 144, pp.163-74.

46. Kujundžić G, Ileš Š, Matuško J, Vašak M, 'Optimal charging of valve-regulated lead-acid batteries based on model predictive control', Applied Energy, vol 187, pp.189-202(2017).

47. Zhang WL, Yin J, Lin ZQ, Shi J, Wang C, Liu DB, Wang Y, Bao $\mathrm{JP}$, Lin HB, 'Lead-carbon electrode designed for renewable energy storage with superior performance in partial state of charge operation', Journal of Power Sources,vol 342, pp.18391(2017).

48. Kuo TJ, Lee KY, Huang CK, Chen JH, Chiu WL, Huang CF, Wu $\mathrm{SD}$, 'State of charge modeling of lithium-ion batteries using dual exponential functions', Journal of Power Sources, vol 315 , pp.331-8.(2016)

49. Abdel-Monem M, Trad K, Omar N, Hegazy O, Van den Bossche P, Van Mierlo J, 'Influence analysis of static and dynamic fastcharging current profiles on ageing performance of commercial lithium-ion batteries', Energy,(2016).

50. Lian B, Sims A, Yu D, Wang C, Dunn RW, 'Optimizing LiFePO4 Battery Energy Storage Systems for Frequency Response in the UK System', IEEE Transactions on Sustainable Energy, vol 8(1) ,pp.385-94(2017)

51. Stroe DI, Knap V, Swierczynski M, Stan A, Teodorescu R, 'Operation of Grid-Connected Lithium-Ion Battery Energy Storage System for Primary Frequency Regulation: A Battery Lifetime Perspective',IEEE Transactions on Industry Applications, (2016).

52. Opitz A, Badami P, Shen L, Vignarooban K, Kannan AM, 'Can LiIon batteries be the panacea for automotive applications?', Renewable and Sustainable Energy Reviews, vol 68, pp.68592(2017).

53. Qiang Z, Chen YM, Xia Y, Liang W, Zhu Y, Vogt BD, 'Ultra-long cycle life, low-cost room temperature sodium-sulfur batteries enabled by highly doped (N, S) nanoporous carbons',Nano Energy, vol 32, pp.59-66(2017).

54. Kim SI, Park WI, Jung K, Kim CS, 'An innovative electronicallyconducting matrix of the cathode for sodium sulfur battery', Journal of Power Sources, vol 320:37-42(2016).
55. Pourabdollah K, 'Development of electrolyte inhibitors in nickel cadmium batteries', Chemical Engineering Science, vol 160, pp.304-12(2017).

56. Belgacem YB, Khaldi C, Lamloumi J, 'The effect of the discharge rate on the electrochemical properties of AB3-type hydrogen storage alloy as anode in nickel-metal hydride batteries', International Journal of Hydrogen Energy(2017).

57. Sessa SD, Palone F, Necci A, Benato R, 'Sodium-nickel chloride battery experimental transient modelling for energy stationary storage', Journal of Energy Storage, vol 9, pp.40-6(2017).

58. Sessa SD, Crugnola G, Todeschini M, Zin S, Benato R, 'Sodium nickel chloride battery steady-state regime model for stationary electrical energy storage', Journal of Energy Storage,vol 6, pp.105-15(2016).

59. Alvarado-Flores J, 'Comparative study of different fuel cell technologies',Boletin de la Sociedad Espanola de CeramicayVidrio,vol52(3), pp.105-17(2013).

60. Mekhilef S, Saidur R, Safari A, 'Comparative study of different fuel cell technologies', Renewable and Sustainable Energy Reviews, vol 16(1), pp.981-9(2012).

61. Sharaf OZ, Orhan MF, 'An overview of fuel cell technology: Fundamentals and applications',Renewable and Sustainable Energy Reviews, vol 32, pp.810-53(2014).

62. Marino MG, Kreuer KD, 'Alkaline stability of quaternary ammonium cations for alkaline fuel cell membranes and ionic liquids', ChemSusChem, vol 8(3), pp.513-23(2015).

63. Yang Y, Wang J, Zheng J, Li S, Zhang S, 'A stable anion exchange membrane based on imidazolium salt for alkaline fuel cell', Journal of Membrane Science,vol 467, pp.48-55(2014).

64. Zhao Y, Yu H, Xie F, Liu Y, Shao Z, Yi B, 'High durability and hydroxide ion conducting pore-filled anion exchange membranes for alkaline fuel cell applications. Journal of Power Sources', vol 269, pp.1-6(2014)

65. Chen X, Wang Y, Cai L, Zhou Y, 'Maximum power output and load matching of a phosphoric acid fuel cell-thermoelectric generator hybrid system', Journal of Power Sources, vol 294, pp.430-6(2015).

66. Yang $\mathrm{P}$, Zhang $\mathrm{H}, \mathrm{Hu} \mathrm{Z}$, 'Parametric study of a hybrid system integrating a phosphoric acid fuel cell with an absorption refrigerator for cooling purposes', International Journal of Hydrogen Energy, vol 41(5), pp.3579-90(2016).

67. Chen X, Wang Y, Zhao Y, Zhou Y, 'A study of double functions and load matching of a phosphoric acid fuel cell/heat-driven refrigerator hybrid system', Energy, vol 101, pp.359-65(2016).

68. Sharifzadeh M, Meghdari M, Rashtchian D, 'Multi-objective design and operation of Solid Oxide Fuel Cell (SOFC) Triple Combined-cycle Power Generation systems: Integrating energy efficiency and operational safety', Applied Energy, vol185, pp.345-61(2017).

69. Medvedev D, Brouzgou A, Demin A, Tsiakaras P, 'ProtonConducting Electrolytes for Solid Oxide Fuel Cell Applications', In Advances in Medium and High Temperature Solid Oxide Fuel Cell Technology, pp.77-118. (2017).

70. Eveloy V, Karunkeyoon W, Rodgers P, Al Alili A, 'Energy, exergy and economic analysis of an integrated solid oxide fuel cell-gas turbine-organic Rankine power generation system', International Journal of Hydrogen Energy',vol 41(31) , pp.13843-58(2016).

71. Açıkkalp E, 'Performance analysis of irreversible molten carbonate fuel cell-Braysson heat engine with ecological objective approach', Energy Conversion and Management, vol 132, pp.432-7(2017).

72. Dimopoulos GG, Stefanatos IC, Kakalis NM, 'Exergy analysis and optimisation of a marine molten carbonate fuel cell system in simple and combined cycle configuration', Energy Conversion and Management, vol 107:10-21(2016).

73. Mehmeti A, Santoni F, Della Pietra M, McPhail SJ, 'Life cycle assessment of molten carbonate fuel cells: State of the art and strategies for the future',Journal of Power Sources,vol 308, pp.97-108(2016).

74. Sebastián $\mathrm{D}$, Baglio $\mathrm{V}$, Aricò $\mathrm{AS}$, Serov A, Atanassov $\mathrm{P}$, 'Performance analysis of a non-platinum group metal catalyst based on iron-aminoantipyrine for direct methanol fuel cells', Applied Catalysis B: Environmental,vol 182, pp.297-305(2016).

75. Colpan CO, Ouellette D, Glüsen A, Müller M, Stolten D, 'Reduction of methanol crossover in a flowing electrolyte-direct methanol fuel cell', International Journal of Hydrogen Energy(2017) 


\section{Ravi Dharavath, I. Jacob Raglend, S. Prabhakar Karthikeyan and J. Belwin Edward./}

\section{Journal of Engineering Science and Technology Review 11 (5) (2018) 61 - 75}

76. Li Y, Wang $\mathrm{H}, \mathrm{Wu} \mathrm{Q}, \mathrm{Xu} \mathrm{X}, \mathrm{Lu} \mathrm{S}$, Xiang Y, 'A poly (vinyl alcohol)-based composite membrane with immobilized phosphotungstic acid molecules for direct methanol fuel cells',ElectrochimicaActa,vol 224, pp.369-77(2017).

77. Das V, Padmanaban S, Venkitusamy K, Selvamuthukumaran R, Blaabjerg F, Siano P, 'Recent advances and challenges of fuel cell based power system architectures and control-A review', Renewable and Sustainable Energy Reviews, vol 73, pp.108(2017).

78. Cetinbas FC, Ahluwalia RK, Kariuki N, De Andrade V, Fongalland D, Smith L, Sharman J, Ferreira P, Rasouli S, Myers DJ, 'Hybrid approach combining multiple characterization techniques and simulations for microstructural analysis of proton exchange membrane fuel cell electrodes',Journal of Power Sources,vol 344, pp.62-73(2017).

79. Kaur R, Krishnasamy V, Muthusamy K, Chinnamuthan P, 'A novel proton exchange membrane fuel cell based power conversion system for telecom supply with genetic algorithm assisted intelligent interfacing converter',Energy Conversion and Management, vol 136, pp.173-83(2017).

80. Thimmappa R, Kottaichamy AR, Devendrachari MC, Aralekallu S, Shafi SP, Gautam M, Kotresh HM, Thotiyl MO, 'Proton Exchange Membrane Fuel Cell with a Pt-free Cathode and a Freely Diffusing Electron Acceptor',ChemElectroChem(2017).

81. Baricco M, Bang M, Fichtner M, Hauback B, Linder M, Luetto C, Moretto P, Sgroi M, 'SSH2S: Hydrogen storage in complex hydrides for an auxiliary power unit based on high temperature proton exchange membrane fuel cells', Journal of Power Sources, vol 342, pp.853-60(2017).

82. Won W, Kwon H, Han JH, Kim J, 'Design and operation of renewable energy sources based hydrogen supply system: Technology integration and optimization', Renewable Energy,vol 103, pp.226-38(2017).

83. Kim M, Kim J, 'Optimization model for the design and analysis of an integrated renewable hydrogen supply (IRHS) system: Application to Korea's hydrogen economy',International Journal of Hydrogen Energy, vol 41(38), pp.16613-26(2016).

84. Niaz S, Manzoor T, Pandith AH, 'Hydrogen storage: Materials, methods and perspectives',Renewable and Sustainable Energy Reviews,vol 50, pp.457-69(. 2015).

85. Deshmukh MK, Deshmukh SS, 'Modeling of hybrid renewable energy systems',Renewable and Sustainable Energy Reviews, vol 12(1), pp.235-49(2008)

86. Mahesh A, Sandhu KS, 'Hybrid wind/photovoltaic energy system developments: Critical review and findings', Renewable and Sustainable Energy Reviews, vol 52, pp.1135-47(2015).

87. Zahraee SM, Assadi MK, Saidur R, 'Application of Artificial Intelligence Methods for Hybrid Energy System Optimization', Renewable and Sustainable Energy Reviews,vol 66, pp.61730(2016).

88. Abbes D, Martinez A, Champenois G, Robyns B, 'Real-time supervision for a hybrid renewable power system emulator', Simulation Modeling Practice and Theory, vol 42, pp.5372(2014).

89. Krishna KS, Kumar KS, 'A review on hybrid renewable energy systems', Renewable and Sustainable Energy Reviews, vol 52, pp.907-16(2015)

90. Hong CM, Ou TC, Lu KH, 'Development of intelligent MPPT (maximum power point tracking) control for a grid-connected hybrid power generation system', Energy, vol 50:270-9(2013).

91. Kazem HA, Al-Badi HA, Al Busaidi AS, Chaichan MT, 'Optimum design and evaluation of hybrid solar/wind/diesel power system for Masirah Island',Environment, Development, and Sustainability, pp.1-8(2016).

92. Maatallah T, Ghodhbane N, Nasrallah SB, 'Assessment viability for hybrid energy system (PV/wind/diesel) with storage in the northernmost city in Africa, Bizerte, Tunisia. Renewable and Sustainable Energy Reviews, vol 59, pp.1639-52(2016).

93. Mangu B, Akshatha S, Suryanarayana D, Fernandes BG, 'GridConnected PV-Wind-Battery-Based Multi-Input TransformerCoupled Bidirectional DC-DC Converter for Household Applications',IEEE Journal of Emerging and Selected Topics in Power Electronics, vol 4(3), pp.1086-95(2016).

94. Sekhar PC, Mishra S, 'Storage free smart energy management for frequency control in a diesel-PV-fuel cell-based hybrid $\mathrm{AC}$ microgrid',IEEE transactions on neural networks and learning systems, vol 27(8), pp.1657-71(2016).
95. Dreidy M, Mokhlis H, Mekhilef S, 'Inertia response and frequency control techniques for renewable energy sources: A review',Renewable and Sustainable Energy Reviews, vol 69, pp.144-55(2017).

96. Dufo-López R, Cristóbal-Monreal IR, Yusta JM, 'Stochasticheuristic methodology for the optimisation of components and control variables of PV-wind-diesel-battery stand-alone systems', Renewable Energy,vol 99, pp.919-35(2016).

97. Banos R, Manzano-Agugliaro F, Montoya FG, Gil C, Alcayde A, Gómez J, 'Optimization methods applied to renewable and sustainable energy: A review',Renewable and Sustainable Energy Reviews, vol 15(4), pp.1753-66(2011).

98. Asadi E, Sadjadi S, 'Optimization methods applied to renewable and sustainable energy: A review', Uncertain Supply Chain Management. vol 5(1), pp.1-26(2017).

99. Philip J, Jain C, Kant K, Singh B, Mishra S, Chandra A, Al-Haddad $\mathrm{K}$, 'Control and implementation of a standalone solar photovoltaic hybrid system', In Industry Applications Society, Annual Meeting, pp.1-8. (2015).

100.Merei G, Berger C, Sauer DU, 'Optimization of an off-grid hybrid PV-Wind-Diesel system with different battery technologies using a genetic algorithm. Solar Energy',vol 97, pp.46073(2013).

101.Siddaiah R, Saini RP, 'A review of planning, configurations, modeling and optimization techniques of hybrid renewable energy systems for off-grid applications',Renewable and Sustainable Energy Reviews, vol 58, pp.376-96(2016).

102.Nehrir MH, Wang C, Strunz K, Aki H, Ramakumar R, Bing J, Miao Z, Salameh Z, 'A review of hybrid renewable/alternative energy systems for electric power generation: Configurations, control, and applications',IEEE Transactions on Sustainable Energy,vol 2(4), pp.392-403(2011).

103.Maleki A, Pourfayaz F, 'Sizing of stand-alone photovoltaic/wind/diesel system with battery and fuel cell storage devices by harmony search algorithm. Journal of Energy Storage,vol 2, pp.30-42(2015).

104. Ogunjuyigbe AS, Ayodele TR, Akinola OA, 'Optimal allocation and sizing of PV/Wind/Split-diesel/Battery hybrid energy system for minimizing life cycle cost, carbon emission and dump energy of theremote residential building',Applied Energy,vol 171, pp.153-71(2016).

105. Charfi S, Atieh A, Chaabene M, 'Modeling and cost analysis for different $\mathrm{PV} /$ battery/diesel operating options driving a load in Tunisia, Jordan and KSA', Sustainable Cities and Society, vol 25, pp.49-56(2016).

106.Luna-Rubio R, Trejo-Perea M, Vargas-Vázquez D, Ríos-Moreno GJ, 'Optimal sizing of renewable hybrids energy systems: A review of methodologies,Solar Energy,vol 86(4) , pp.107788(2012).

107.Al-Sharafi A, Sahin AZ, Ayar T, Yilbas BS, 'Techno-economic analysis and optimization of solar and wind energy systems for power generation and hydrogen production in Saudi Arabia', Renewable and Sustainable Energy Reviews, vol 69:33-49, pp.358-66(2017).

108.Dekkiche M, Tahri T, Ahmed B, Belmadani B, 'Sizing and optimisation of a standalone hybrid system for electrification of a remote site at Ouled Fares, Algeria', Advances in Materials and Processing Technologies, vol 3(1), pp.125-34(2017).

109.Hossain M, Mekhilef S, Olatomiwa L, 'Performance evaluation of a stand-alone PV-wind-diesel-battery hybrid system feasible for a large resort center in South China Sea, Advances in Materials and Processing Technologies, vol 3(1), pp.125-34(2017).

110.Bukar A, Mai KB, 'Economic Assessment of a PV/Diesel/Battery Hybrid Energy System for a Non-Electrified Remote Village in Nigeria', European Journal of Engineering Research and Science, vol2(1)( 2017).

111. Yang H, Zhou W, Lu L, Fang Z, 'Optimal sizing method for standalone hybrid solar-wind system with LPSP technology by using a genetic algorithm', Solar energy. vol 82(4) , pp.354-67(2008).

112.Operation O, Optimal Operation of Micro grids Including Photovoltaic / Wind / Diesel, Micro grids of. Articlevol 7:25060(2016).

113.Boonbumroong U, Pratinthong N, Thepa S, Jivacate C, Pridasawas $\mathrm{W}$, 'Particle swarm optimization for AC-coupling stand-alone hybrid power systems,' Solar Energy. vol 85(3), pp.560-9(2011).

114.Dufo-López R, Fernández-Jiménez LA, Ramírez-Rosado IJ, ArtalSevil JS, Domínguez-Navarro JA, Bernal-Agustín JL, ' Daily operation optimisation of hybrid stand-alone system by model 
Ravi Dharavath, I. Jacob Raglend, S. Prabhakar Karthikeyan and J. Belwin Edward./

Journal of Engineering Science and Technology Review 11 (5) (2018) 61 - 75

predictive control considering ageing model',Energy Conversion and Management, vol 134, pp.167-77(2017).

115.Mehrabankhomartash M, Rayati M, Sheikhi A, Ranjbar AM, 'Practical battery size optimization of a PV system by considering individual customer damage function, 'Renewable and Sustainable Energy Reviews, vol 67, pp.36-50(2017).

116.Majidi M, Nojavan S, Esfetanaj NN, Najafi-Ghalelou A, Zare K, 'A multi-objective model for optimal operation of a battery/PV/fuel cell/grid hybrid energy system using weighted sum technique and fuzzy satisfying approach considering responsible load management',Solar Energy, vol 144, pp.79-89(2017).

117.Al-Sharafi A, Yilbas BS, Sahin AZ, Ayar T, 'Performance assessment of hybrid power generation systems: Economic and environmental impacts',Energy Conversion and Management, vol 132, pp.418-31(2017).

118.Vani N, Khare V, 'Rural electrification system based on hybrid energy system model optimization using HOMER', Canadian Journal of Basic and Applied Sciences,vol 1(01) , pp.1925(2013).

119.Barzola J, Espinoza M, Cabrera F, 'Analysis of Hybrid Solar/Wind/Diesel Renewable Energy System for off-grid Rural Electrification', International Journal of Renewable Energy Research (IJRER), vol 6(3), pp.1146-52(2016).
120.Goel S, Ali SM, 'Cost analysis of solar/wind/diesel hybrid energy systems for Telecom tower by using HOMER. International Journal of Renewable Energy Research (IJRER), vol (2) , pp.30511(2014).

121.Hossain M, Mekhilef S, Olatomiwa L, 'Performance evaluation of a stand-alone PV-wind-diesel-battery hybrid system feasible for a large resort center in South China Sea, Malaysia', Sustainable Cities and Society, vol 28, pp.358-66(2017).

122.Wang C, Nehrir MH, 'Power management of a stand-alone wind/photovoltaic/fuel cell energy system', IEEE transactions on energy conversion, vol 23(3), pp.957-67(2008).

123.Dursun E, Kilic O, 'Comparative evaluation of different power management strategies of a stand-alone PV/Wind/PEMFC hybrid power system', International Journal of Electrical Power \& Energy Systems,vol 34,pp.(1):81-9(2012).

124.Khan MJ, Yadav AK, Mathew L, 'Techno economic feasibility analysis of different combinations of PV-Wind-Diesel-Battery hybrid system for telecommunication applications in different cities of Punjab, India', Renewable and Sustainable Energy Reviews, vol76, pp.577-607(2017).

125.http://www.mondaq.com/india/x/531362/Renewables/The+MNRE + Introduces $+\mathrm{A}+$ Policy + For + Hybrid + Solar+Wind + Power+Projec ts

density of air $\left(\mathrm{kg} / \mathrm{m}^{3}\right)$,

area cut by the turbine blades $\left(\mathrm{m}^{2}\right)$

Coefficient of the power

specific turbine rotor speed ( $\mathrm{rad} / \mathrm{s})$

wind velocity $(\mathrm{m} / \mathrm{s})$

turbine blade radius (m)

Rated power $(\mathrm{kW})$

cut in value of the $\operatorname{speed}(\mathrm{m} / \mathrm{s})$

cut out value of the $\operatorname{speed}(\mathrm{m} / \mathrm{s})$

wind generator rated speed $(\mathrm{m} / \mathrm{s})$

overall developed power $(\mathrm{kW})$

$P_{W G}(T)$

$P_{W G}(t)$

power developed from individual generator $(\mathrm{kW})$

Number of wind turbine generators

Safety factor (commonly 120\%)

output power of the wind turbine $(\mathrm{kW})$

$P_{L}$

Required load power $(\mathrm{kW})$

Fuel flow $(\mathrm{kg} / \mathrm{s})$

mechanical torque after the delay time $\mathrm{t}_{1}(\mathrm{~N}-\mathrm{m})$

Engine torque constant(pu)

synchronous, transient and sub transient reactance of qaxis $(\Omega)$

time constant of the open circuit, sub-transient time constants

diesel generator output power( $\mathrm{kW})$

Fuel price $(\$ / L)$

Power generated from Solar Photovoltaic system(kW)

sub transient voltages with reference $\mathrm{d}$-axis and q-axis

(V)

Power generation from Diesel generation system $(\mathrm{kW})$

Power from Fuel cell(kW)

Power supply to electrolyzer $(\mathrm{kW})$

Platinum

Platinum sulphur oxide

Hydrogen dioxide 
Ravi Dharavath, I. Jacob Raglend, S. Prabhakar Karthikeyan and J. Belwin Edward./ Journal of Engineering Science and Technology Review 11 (5) (2018) 61 - 75

$\begin{array}{llll}\mathrm{H}^{+} & \text {Hydrogen-ion } & \mathrm{Li}^{+} & \text {Lithium-ion } \\ \mathrm{C} & \text { Carbon } & \mathrm{Li}_{n} \mathrm{C} & \text { Lithium carbonate } \\ \mathrm{Na}^{+} & \text {Sodium-ion } & \mathrm{Cd}(\mathrm{OH})_{2} & \text { Cadmium hydroxide } \\ \mathrm{Cd} & \text { Cadmium } & \mathrm{OH}^{-} & \text {hydroxide } \\ \mathrm{LiXXO} & \text { Lithium xenon oxidised } & \mathrm{Ni}_{2}(\mathrm{OH})_{2} & \text { Nickel hydroxide } \\ \mathrm{NiOOH} & \text { Nickel oxy hydroxide } & \mathrm{NiCl}_{2} & \text { Nickel Chloride }\end{array}$

